\title{
Appreciation
}

\section{Vernon Young and the development of current knowledge in protein and amino acid nutrition Vernon Young 1937-2004}

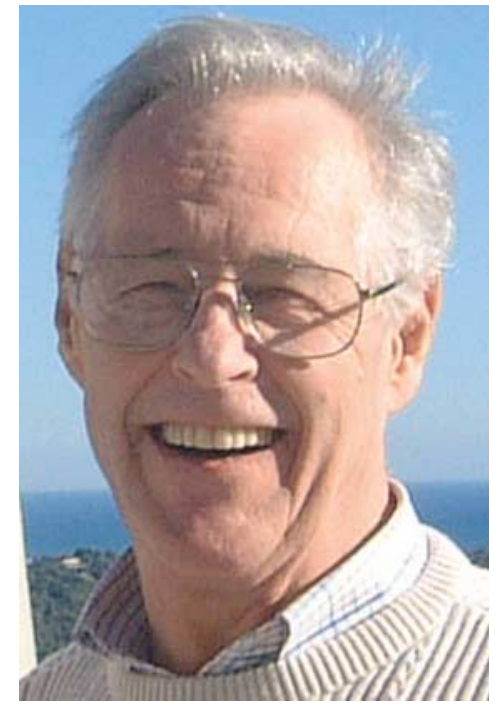

15 November 1937- 30 March 2004

\section{Personal note}

Vernon Young, undoubtedly the best-known and most highly honoured nutritionist globally of his generation and a unique personality in the history of nutrition, died 30 March 2004 of complications from renal cancer. He was 66. At the time of his death he held posts at Massachusetts Institute of Technology (MIT), Massachusetts General Hospital, Harvard Medical School, Tufts University, and was Director of the Mass Spectrometry Facility at Shriners Burns Institute, Boston. His many honours and prizes started in 1973 with the Mead-Johnson Award from the American Institute of Nutrition, included the BristolMyers Squibb/Mead Johnson Award for Distinguished Achievement in Nutrition Research in 1995, the Danone International Prize for Nutrition in 1997 and most recently the Conrad Elvehjem Award from the American Society for Nutritional Sciences in 2003. He was elected to the National Academy of Sciences USA in 1990 and to the Institute of Medicine in 1993 in recognition of his scientific accomplishments in the field of human nutrition. In 2001, he was named to the Board of Directors of Nestlé Corporation, which sought his nutritional expertise.

Vernon was born in Rhyl, North Wales on 15 November 1937, but lived in Cardiff from an early age. His twin sister says that his interests in agriculture developed during his visits to an uncle's farm in Nottinghamshire. He studied agriculture at Reading (BSc 1959) and Cambridge (postgraduate diploma 1960). He moved to the University of California at Davis in 1960 to gain his $\mathrm{PhD}$ in 1965 for work on $\mathrm{Ca}$ and $\mathrm{P}$ homeostasis in sheep, moving to MIT to work with Nevin Scrimshaw and meeting Janice his wifeto-be that same year.

His work was characterised by three main interests; human protein and amino acid metabolism and requirements, nutrition and ageing and nutrient bioavailability. His output was quite remarkable (especially given two triple bypass operations), just short of 600 full-length peer-reviewed papers, book chapters and reviews, more than one paper per month for 42 years and at his peak in 1980 nearly one paper per week (Fig. 1). He was a man who lived for his work and thought about little else apart from his wife Janice and his five children.

Throughout this work I have had very similar interests, closely following Vernon's work having first met him in the late 1960s when a life-long friendship was established with him and his wife. This was notwithstanding the lively debate which characterised our scientific relationship. In what follows I have made no attempt to present a comprehensive review of his work, instead presenting a personal and selective view of his major interests in the context of the development of our understanding of protein and amino acid nutrition.

\section{Defining protein requirements}

As detailed in the excellent series on the history of nutritional science (Carpenter, 2003a-d), following the identification of $\mathrm{N}$ by Rutherford in the late 18th century, our understanding of the nutritional importance of protein began in Paris 


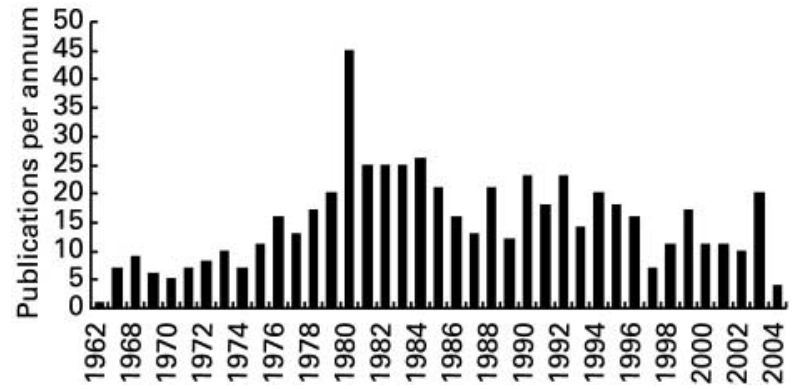

Fig. 1. Full-length peer-reviewed publications, book chapters and reviews written by Vernon Young between 1962 and 2004. Publications between 1962 and 2004 numbered 598.

in the early 19th century. This is when the essentiality of dietary $\mathrm{N}$ was established by the feeding trials on dogs by Magendie and the balance studies on herbivores of Boussingault. These studies, together with the chemical identification of protein by Mulder, established protein as the determinant of food 'quality' and the food constituent which dominated nutritional science for the rest of the 19th century. Furthermore, on the basis of measuring the protein intakes of working men and soldiers, all meat eaters of course, Voit and Peltenkofer, Atwater and Rubner argued that relatively large amounts of protein, 120-130 g, were needed in the diet. There were some dissenting voices, notably John Harvey Kellogg and most famously Chittendon, who both advocated less meat and lower protein intakes as part of the healthy diet. Nevertheless, from the early 20 th century the majority view was that health and especially fitness depended on generous amounts of protein in the diet, especially meat, and that populations that existed on low levels of protein were usually extremely unfit. This view was reinforced by Cecily Williams' suggestion that kwashiorkor, which she had described in West Africa in the 1930s, was due to protein deficiency (Williams, 1935). The ultimate statement of the primacy of protein in the diet came in a report published in 1968 under the auspices of the UN identifying widespread protein deficiency and calling for 'a global strategy to deal with the impending protein crisis' (United Nations, 1968). Thus, provision of protein came to dominate international aid initiating the green revolution to improve yields of cereals in the developing world and with soyabean production becoming of extraordinary importance within US agricultural production.

Whilst this dominant role of protein was not universal and seen as 'a protein myth' by some (see McLaren, 1974; Waterlow \& Payne, 1975), nevertheless this was the climate of opinion within which the modern era of international expert committees to define protein requirements had begun with a report from the FAO in 1957 (Food \& Agriculture Organization, 1957). This first report was followed quickly by a second from the FAO and WHO in 1965 (Food \& Agriculture Organization/ World Health Organization, 1965). It was at this point that Vernon Young's work, which was to dominate the next 40 years of the development of our understanding of protein and amino acid requirements, began.

The 1965 FAO/WHO report (Food \& Agriculture Organization/World Health Organization, 1965) had derived a safe protein requirement value for adults of $0.89 \mathrm{~g}$ animal protein $/ \mathrm{kg}$ per $\mathrm{d}(1.12 \mathrm{~g}$ plant proteins $/ \mathrm{kg}$ per d). The requirement had been derived by a factorial method based on an obligatory $\mathrm{N}$ loss (ONL) value (losses on a protein-free diet), with additions for interindividual variability. The database from which these values were derived was very limited, so Young and Scrimshaw immediately started studies to better define the ONL, publishing initial data in 1968 (Young \& Scrimshaw, 1968; Young's first Nature paper, Young et al. 1968b) and the definitive study in 1972 (Scrimshaw et al. 1972). These data formed the basis of the next Food \& Agriculture Organization/World Health Organization (1973) report which was a much more thorough, scientifically based, document than any previous one. Although N-balance data were examined by the Committee, these were quite limited at the time, so the report writers again adopted a factorial method but used the new extensive data from Young and Scrimshaw for the ONL. Because these were much lower than the previous values used in the 1965 report, this resulted in an adult protein requirement, after correction for efficiency of utilisation and interindividual variability, of $0.57 \mathrm{~g} / \mathrm{kg}$ per $\mathrm{d}$. This lowering of the protein requirement had a dramatic effect within the nutritional community and began a major controversy.

To understand the impact of this report (Food \& Agriculture Organization/World Health Organization, 1973), it is important to recognise the major problem within protein nutrition which is still unresolved. This is how to identify protein deficiency in the absence of any definitive markers of nutritional status in relation to protein adequacy, an especially difficult problem in adults. Without such markers, protein deficiency can only be defined in terms of intakes below an assumed requirement level. Thus the prevalence of protein deficiency changes as protein requirements change and the 1973 report, by lowering the protein requirement, reduced the prevalence of protein deficiency; this was contrary to the spirit of the 1968 UN 'impending protein crisis' report (United Nations, 1968).

Young and Scrimshaw's extensive studies at MIT became the dominant influence within this controversy. They reported a major series of $\mathrm{N}$-balance studies on young adult men, both short- and long-term studies. The short-term balances (Young et al. 1973) essentially confirmed the 1973 value (Food \& Agriculture Organization/World Health Organization, 1973) consistent with contemporary work from Calloway \& Margen (1971) at the University of California at Berkeley, the other major centre working on protein requirements at the time. However, Young and Scrimshaw's long-term balances (Garza et al. 1977a,b, 1978) carried out specifically to test the safety of the 1973 safe allowance $(0.57 \mathrm{~g}$ protein) showed that this level of intake resulted in negative $\mathrm{N}$ balance, loss of lean body mass, deteriorating values for serum protein and increased serum transaminases unless additional energy or $\mathrm{N}$ was fed. These alarming findings led to calls by Scrimshaw (for example, Scrimshaw, 1977) for an upwards re-evaluation of the 1973 report recommendations, and to the initiation of an international programme of short-term balance studies with 
a common methodology organised by Young and Scrimshaw through the UN University World Hunger Programme. The outcome of these studies, reported in early 1981 , was a mean requirement of $0.6 \mathrm{~g} / \mathrm{kg}$ per $\mathrm{d}$ (Torun et al. 1981) and a safe allowance 20-30\% higher than this. As a result, the agenda of the next FAO/WHO/UN University meeting in 1981 was set and the report (Food \& Agriculture Organization/World Health Organization/United Nations University, 1985), on the basis of both short- and long-term balance data, duly raised the safe allowance to $0.75 \mathrm{~g} / \mathrm{kg}$ per $\mathrm{d}$. This value was adopted by national bodies around the world. Apart from N-balance studies on the elderly (Gersovitz et al. 1982) following up earlier work (Uauy et al. $1978 a$ ) and a major series of studies on the nutritional value of soyabean protein (Istfan et al. 1983a,b; Scrimshaw et al. 1983; Wayler et al. 1983; Young et al. 1984), the early 1980s were to mark the end of Young's N-balance studies aimed at the adult protein requirement. The magnitude of this part of his work is apparent from his recent meta-analysis of all published data on adults (Rand et al. 2003), used as the basis of the recent US dietary reference intakes report on protein requirements (Institute of Medicine, 2002). Of the 118 assembled references, thirty-two studies were his work, with many more reported by workers he trained at MIT.

\section{Protein metabolism in skeletal muscle}

A second main interest which he developed soon after arriving in MIT from Davis was the regulation of protein metabolism in skeletal muscle, in part inspired by his second mentor at MIT, Hamish Munro. Against the background of interest in malnutrition, the mechanisms of growth failure and tissue wasting had emerged as a major focus of interest in the 1960s. From the mid $1960 \mathrm{~s}$, the preparation and examination of ribosome fractions from skeletal muscle became a fruitful approach to the study of protein synthesis (Chen \& Young, 1968), especially important in muscle where changes in protein synthesis in response to insulin and other factors had been shown to occur very rapidly (for example, Young et al. 1968a). Young published a series of studies of the effects of dietary protein, infection and hormones on muscle ribosomes focusing on the translational phase of protein synthesis at the level of both initiation and elongation. However, at that time there were several competing groups working on muscle and to his great disappointment his National Institutes of Health grant-support for his muscle work, which he saw as his first fully independent research programme, was not renewed. He told me at the time that he believed this reflected a view that nutritionists should not be working within the emerging field of cellular and molecular biology. This aspect of his work ended in 1974 with a publication relating to elongation factor 2 in rat skeletal muscle during protein depletion and re-feeding (Alexis et al. 1974).

However, in parallel with this in vitro work he was developing a new approach to the in vivo study of muscle protein degradation. During the preparation of a major review on protein metabolism in skeletal and cardiac muscle for Munro's classic series on mammalian protein metabolism (Young, 1970) he became interested in the presence in specific muscle proteins of methylated amino acids of which 3-methylhistidine only occurred in actin and some types of myosin heavy chain. This led to a series of classic studies showing that this was a post-translational modification and that 3-methylhistidine, once released during actin proteolysis, was not re-utilised for protein synthesis. Since it was not further metabolised in vivo its urinary excretion could serve as a measure of skeletal muscle proteolysis (Young \& Munro, 1978). This paper was the basis of his Rank Prize in Nutrition in 1989, and became a citation classic in 1992, demonstrating how widely adopted the method became. Although subsequent work has showed that actin turnover in non-muscle tissue is a major fraction of urinary 3-methylhistidine excretion, reducing the specificity of the method (Millward et al. 1980; Millward \& Bates, 1983), the idea was a good example of Young's single-minded and inventive approach to science.

\section{Stable isotopes, protein turnover and amino acid requirements}

Young's best-known work today relates to his development of the use of stable isotopes in his search for methods to build on and replace $\mathrm{N}$ balance in assessing protein and amino acid requirements. The use of stable isotopes to probe the dynamic aspects of protein metabolism was initiated by the brilliant studies of Rudolf Schoenheimer in the late 1930 s soon after ${ }^{15} \mathrm{~N}$ and ${ }^{2} \mathrm{H}$ became available. These studies were developed by Rittenberg and others, after Schoenheimer's untimely death in 1941, into increasingly mathematically complex compartmental analyses with ${ }^{15} \mathrm{~N}$ tracers. Few could understand these methods and development was slow until in the early 1960s John Waterlow working for the UK Medical Research Council in Jamaica rationalised and simplified the methodology by introducing stochastic steady-state tracer methodologies with ${ }^{15} \mathrm{~N}$ tracers (glycine, urea and ammonium salts) in human subjects and $\left[{ }^{14} \mathrm{C}\right]$ lysine studies in animals (Waterlow et al. 1978). The motivation behind this work was that body protein is in a dynamic state, with overall rates of protein synthesis several-fold greater than protein intakes. Thus, the tissue protein mass can be controlled not only by the relative rates of dietary protein supply and body $\mathrm{N}$ losses, as measured by $\mathrm{N}$ balance, but also by adaptive changes in the rates of re-utilisation and redistribution of the amino acids released by protein breakdown. This would allow adaptation to varying intakes of protein over a wide range, and conditions such as kwashiorkor represented the consequence of a failure to sufficiently adapt to a reduced intake. Early work on albumin turnover in Jamaica strengthened this view (James \& Hay, 1968). Young was impressed by this work, and adopted Waterlow as one of his mentors. This led to the establishment of appropriate isotope ratio MS facilities at MIT, a rare example of the Third World exporting leading-edge technology to the USA, enabling a series of studies of protein turnover on neonates (Pencharz et al. 1977), children (Kien et al. 1978a,b,c), adults (Steffee et al. 1976), and the 
elderly (Winterer et al. 1976; Uauy et al. 1978b), all aimed at better understanding the protein requirement (Young et al. 1975b). However the pace of this work was slow by Young's standards since isotope ratio MS analysis of ${ }^{15} \mathrm{~N}$ is laborious. The introduction of gas chromatography-MS in selective ion monitoring mode, allowing the automated analysis of isotopic enrichment of amino acids, resulted in a dramatic change of pace. This development of the technology occurred through the work of Bier and Matthews at Washington University at St Louis in the late 1970s with whom Young established a long-standing collaboration, as did the present author and colleagues in the UK (for example, Matthews et al. 1981). Thus, by 1980, gas chromatography-MS facilities had also been established by Halliday in the UK Medical Research Council Unit at Northwick Park.

The most important feature of this phase of Young's work was his early identification of the importance of stable-isotope studies of amino acid oxidation and consequent balance, with ${ }^{13} \mathrm{C}$-labelled amino acids such as leucine, as a means of improving on $\mathrm{N}$ balance. Thus the balance technique, which had hitherto been used to assess the protein or amino acid intake which allowed body $\mathrm{N}$ equilibrium, was extended by utilising the balance of the individual amino acid from measurement of its oxidation as ${ }^{13} \mathrm{CO}_{2}$ production. This allows balance measurements over a period of hours as opposed to days with $\mathrm{N}$ balance. By 1982 Young was starting to report his amino acid oxidation balance studies with ${ }^{13} \mathrm{C}$ tracers as a new approach for the estimation of human amino acid requirements (Meredith et al. 1982). The complete series of ${ }^{13} \mathrm{C}$ balance studies with leucine, valine, lysine and threonine was reported in 1986 over thirty-three pages of a single issue of the American Journal of Clinical Nutrition (Meguid et al. 1986a,b; Meredith et al. 1986; Zhao et al. 1986), an extraordinary amount of work. Protein turnover, as opposed to balance, remained an important part of Young's work for several years, enabling him to identify lower limits of leucine intake in terms of adaptation and accommodation (Young et al. 1987). However, by the end of the 1980s protein and amino acid turnover per se had become of much less importance within his work. Indeed, notwithstanding the explosion of protein-turnover studies in the 1980s and 1990s as gas chromatography-MS selected ion monitoring technology became widespread, Young believed that the initial promise that protein turnover would transform our understanding of protein requirements had not been realised.

The final phase of this aspect of his work involved recognising the limitations of his first ${ }^{13} \mathrm{C}$ amino acid oxidation balance studies and refining the technique to its ultimate limits in terms of $24 \mathrm{~h}{ }^{13} \mathrm{C}$ amino acid oxidation balance studies with his student Antoine El Khoury in MIT which began in 1994 (El-Khoury et al. 1994), and then with Anura Kurpad in India from 1998. With this approach he was able to refine his estimates of the requirements for leucine (Kurpad et al. 2001b, 2003b), lysine (Kurpad et al. 2001a, 2002b, 2003a,c), threonine (Kurpad et al. 2002a) and cystine and methionine (Kurpad et al. $2003 d, 2004)$.

\section{The Massachusetts Institute of Technology amino acid requirement pattern and protein quality}

The most fascinating feature of Young's work on adult amino acid requirements over the final 25 years of his life was the way he organised and reported his stable-isotope work in relation to his proposal for what came to be called the MIT amino acid requirement pattern. Recognition of the concept of amino acid essentiality as the determinant of protein quality arose early in the 19th century through feeding trials with collagen extracted from bones. This showed that collagen protein was demonstrably nutritionally inferior to proteins such as albumin extracted from serum. The advances in chemical analysis of protein and protein hydrolysates in the latter part of the 19th century resulted in the identification of many individual amino acids by the early years of the 20th century. Hopkins isolated tryptophan, which in turn enabled the unusual composition of collagen and especially its lack of any tryptophan to be demonstrated by Kaufman, who showed that gelatin + tryptophan + cystine + tyrosine maintained $\mathrm{N}$ balance in dogs and man. The other protein which aroused interest through its inability to allow the growth of animals was zein, the principal protein extract from maize. Hopkins had shown that mice fed on zein (which contains very low levels of tryptophan) lived longer if they also received a supplement of tryptophan. Thus, the concept of protein quality determined by its amino acid content was established in animals. Also, N-balance studies with adults, such as those by Thomas in 1909 with different foods, rapidly established the importance of protein quality in human nutrition. The final refinements of the basic principle that amino acid content was an important determinant of the nutritional quality of protein were in place by 1915 with the experiments of Osborne \& Mendel (1916), who demonstrated the different amino acid requirement patterns for maintenance and growth. Thus, they not only confirmed the Hopkins findings that rodents fed diets based on zein lost weight and died without tryptophan, but also showed that by supplementing first with tryptophan and then with additional lysine the rats not only maintained weight but also grew (i.e. zein was limited by tryptophan for maintenance and by lysine for growth). After this, the pioneering work of Rose identified all eight essential amino acids needed to maintain $\mathrm{N}$ balance in adult man (Rose, 1957). This work was followed up by studies throughout the USA which quantified the magnitude of amino acid requirements in adult men and women and these data formed the basis of both the Food \& Agriculture Organization/World Health Organization (1973) and the Food \& Agriculture Organization/World Health Organization/ United Nations University (1985) reports on human amino acid requirements. Unfortunately a major flaw in all of these studies resulted in the controversy which raged for 20 years and which dominated Young's work up to the time of his death.

The complete database of N-balance studies aimed at identifying amino acid requirements, examined by the 1973 and 1985 reports (Food and Agriculture Organization/World Health Organization, 1973; Food \& Agriculture Organization/World Health Organization/United 
Nations University, 1985), had been critically reviewed and recalculated by Hegsted (Hegsted, 1963; Irwin \& Hegsted, 1971). Hegsted pointed out that because the plots of amino acid intake on $\mathrm{N}$ balance were curvilinear with very shallow slopes at $\mathrm{N}$ equilibrium, the intake for balance critically depended on the very small changes in balance which related to the assumed value for miscellaneous $\mathrm{N}$ losses (i.e. skin, sweat, hair, etc). Because these losses are so small (4-8 mg N/kg perd) they had been ignored. In fact if small additions to $\mathrm{N}$ losses were made to account for these losses this had significant and in some cases quite marked effects on the intake for $\mathrm{N}$ equilibrium, i.e. the amino acid requirement. However, neither the 1973 nor the 1985 report took this into account and accepted uncorrected values which were, as a consequence, too low. The 1985 report went on to calculate age-related amino acid requirements scoring patterns on the basis of the safe level of proteins, which meant that the scoring pattern for adults involved such low levels of essential amino acids per $g$ protein that all protein sources, including cereal proteins, previously assumed to be deficient in lysine or tryptophan, were nutritionally adequate. Thus protein quality was identified as being unimportant for adults.

In retrospect, given that the major focus of the 1985 report (Food \& Agriculture Organization/World Health Organization/United Nations University, 1985) was on increasing the adult protein requirement, the abolition of the importance of protein quality in adults might be thought of as a very surprising decision of the committee. In fact the long-standing controversy of the lysine requirement and the nutritional importance of its low level in cereal proteins, especially wheat, has never been entirely straightforward. As recently highlighted by Carpenter $(2003 d)$, wartime studies in the UK by Widdowson and McCance had shown that 9-10-year-old orphanage children studied over 6 months grew in weight and height some $25 \%$ faster than the general population on a breadbased diet with only $14 \%$ from animal (milk) foods, with no advantage observed when nearly one half the protein was from milk. In fact, in children, with energy needs much higher than adults, their protein needs can be satisfied by much less protein-dense foods (Millward \& Jackson, 2004), as evident by the low level of protein in breast milk (6\% energy) which mediates rapid postnatal growth. Because wheat is a relatively high-protein cereal (12-16\% energy) and the energy intakes of children of this age are high, the protein content of the diet of the orphanage children (12\% energy) provided them with two to three times their protein needs so that protein quality ceased to be important. More importantly, studies examining the nutritional quality of wheat protein in adults also concluded that wheat-based diets maintained $\mathrm{N}$ balance and fitness (Bolourchi et al. 1968), but these studies were criticised by Young because of their high energy intakes (Rand \& Young, 1999). Furthermore Young's own work comparing isonitrogenous intakes of wheat and beef showed clear differences in their utilisation (Young et al. 1975a).

Whatever the explanation of the Food \& Agriculture Organization/World Health Organization/United Nations University (1985) report's abolition of protein quality contrary to the stated view of one of its authors, by the time that it appeared in 1985 Young was well into the stable-isotope studies described earlier. He was aiming to rectify what he saw as a major flaw in the report and had completed the ${ }^{13} \mathrm{C}$ amino acid oxidation balance studies, described earlier, which were published in 1986. These demonstrated much higher requirement values for all indispensable amino acids examined, most importantly for an increase in the lysine requirement from $12 \mathrm{mg} / \mathrm{kg}$ per $\mathrm{d}$ in the 1973 and 1985 reports (Food \& Agriculture Organization/World Health Organization, 1973; Food \& Agriculture Organization/World Health Organization/United Nations University, 1985 ) to $30 \mathrm{mg} / \mathrm{kg}$ per d. The MIT amino acid requirements pattern was published in 1989 (Young et al. 1989) in what Young believed to be his most important paper entitled 'A theoretical basis for increasing current estimations of the amino acid requirements in adult man, with experimental support'. The key idea was that amino acid requirements for maintenance could be predicted by converting the obligatory $\mathrm{N}$ losses into an isonitrogenous equivalent pattern of obligatory oxidative losses of amino acids (on the basis that amino acids derived from tissue protein gave rise to the obligatory losses), scaled up assuming a $70 \%$ efficiency of dietary amino acid utilisation. Thus, after some adjustments on the basis of his stable-isotope studies the requirements pattern was essentially that of $0.48 \mathrm{~g}$ tissue protein with lower values for lysine $(71 \%)$, threonine $(71 \%)$ and valine $(83 \%)$. In effect this metabolic model was similar to that of the 1973 FAO/WHO report, i.e. a factorial model of a dietary requirement derived from the ONL adjusted for a $70 \%$ efficiency of utilisation.

The MIT amino acid requirements pattern was immediately very controversial in its theoretical origins (Millward, 1990). It was especially controversial because its basic idea, of a maintenance pattern based on tissue protein, meant that requirements for maintenance and growth were similar, contrary to the considerable body of work, largely animal studies, going back to Osborne \& Mendel (1916), pointing to quite different amino acid patterns for maintenance and growth. However Young defended it vigorously both with argument (for example, Young, 1992; Young \& El-Khoury, 1995) and with further experimental work (Marchini et al. 1993; Raguso et al. 1999; Young \& Borgonha, 2000). He was quite happy to organise a session at the 1992 Federation meetings at Anaheim where the arguments could be aired in public in front of a packed auditorium containing the entire US nutrition academic leadership (Millward, 1994; Young, 1994). He remained convinced to the end that his stable-isotope studies in the USA and in India supported the MIT pattern especially in terms of the lysine requirement. He had the satisfaction that the Nutrition Board expert committee, in writing the Institute of Medicine (2002) US dietary reference intakes report, defined a pattern of amino acid requirements which was very similar to the MIT pattern, consequently restoring the importance of protein quality for human adults. Whatever the ultimate verdict on the MIT amino acid requirements pattern, there can be no doubt that the published experimental work aimed at its verification represents a body of knowledge which is invaluable in terms 
of extending both our understanding of amino acid requirements and the methodology and technology necessary for the further work which undoubtedly will be required.

\section{Other unresolved controversies}

\section{Adaptation}

During the period after the Food \& Agriculture Organization/World Health Organization (1973) report the problem of adaptation to low intakes emerged. It was discussed in the Food \& Agriculture Organization/World Health Organization/United Nations University (1985) report and has been often revisited especially by Waterlow (1999) and Jackson (1999, 2000).

According to Scrimshaw (1996) the MIT view at the time, and subsequently, was that the individual adult's requirement is genetically fixed over time with inter- but no intra-individual variability. In contrast to this, at UCLA Berkeley, a different view emerged based on the work of Sukhatme \& Margen (1978). On the basis of a limited number of long-term N-balance studies, they argued for a different definition of the protein requirement. This allowed for intra-individual variability, i.e. adaptation, with a range of intakes within which protein homeostasis could be maintained.

The database on which Sukhatme and Margen developed their ideas was a small series of long-term $\mathrm{N}$ balances at fixed intakes, in which an individual's daily $\mathrm{N}$ output showed serial correlations rather than random fluctuations. Young and Scrimshaw responded to the Sukhatme and Margen model by analysing their own long-term balance data for serial correlations and were unable to identify them (Rand et al. 1979), reporting only random variations in urinary output after correcting for long-term trends. Then, before the $1981 \mathrm{FAO} / \mathrm{WHO} / \mathrm{UN}$ University meeting, Margen reported further data on the extent of serial correlations in long-term $\mathrm{N}$ balances in six subjects on a very low intake similar to the ONL. The intake was $0.36 \mathrm{~g}$ egg protein $/ \mathrm{kg}$ per $\mathrm{d}$, which they interpreted as indicating that this level of $\mathrm{N}$ intake was within the 'adequate' range (N Durkin, DA Ogar, SG Tilve and S Margen, unpublished results). However, most of the subjects lost weight during the study and since no measurements were made of body composition the extent of lean tissue loss was not indicated. Importantly there were no adverse physiological (work performance) or biochemical changes, unlike the MIT studies at a higher intake. Since these further studies of Margen presented to the 1981 FAO/ WHO/UN University meeting had not been (and were never) published, with no other similar evidence for the cyclical patterns of $\mathrm{N}$ loss having been published (at least to my knowledge), and since the arguments of Sukhartme were particularly mathematically abstruse, they have had relatively little impact. In fact this particular argument is a complex one. The existence or not of the Sukhatme and Margen regulatory mechanism controlling $\mathrm{N}$ balance within a range of intakes is an interesting theoretical question. Yet, in one sense the key difference between MIT and Margen was the magnitude of the minimum intake at which $\mathrm{N}$ balance can be achieved at no obvious cost, i.e. $0.35 \mathrm{~g}$ protein $/ \mathrm{kg}$ per $\mathrm{d}$ or $>0.6 \mathrm{~g}$ protein $/ \mathrm{kg}$ per $\mathrm{d}$.

Young firmly rejected the idea of long-term adaptation to intakes much below $0.6 \mathrm{~g} / \mathrm{kg}$ per $\mathrm{d}$, arguing that 'the limits of adaptation are bounded by the safe range of nutrient intakes, ... are similar among healthy populations world wise, ... and are reached over a relatively short time frame' (Young \& Borgonha, 1998). However, Young has never rested on his well-deserved laurels and his approach to those who have challenged his view (for example, Hegsted, 2000), and myself (Millward, 2003; Millward \& Jackson, 2004) has been to perform more studies. With Kurpad he has examined whether adaptive reductions in the lysine requirement occurs in chronically undernourished adult Indian men, showing that, on the contrary, the lysine requirement is increased (Kurpad et al. 2003c). Not prepared to leave it at that they then went on to show that this reflected the presence of intestinal parasites, which when treated, resulted in a value for the lysine requirement 'in the range of $30 \mathrm{mg} / \mathrm{kg}$ per d or possibly less' (Kurpad et al. 2003a). This means that the argument about the importance or relevance of adaptation will no doubt continue, not least by the very large number of researchers worldwide who Young trained and will no doubt continue to carry his flag.

\section{Urea recycling and the de novo synthesis of lysine}

Young's interest in the use of stable isotopes to probe $\mathrm{N}$ metabolism and his close relationship with Waterlow's unit in Jamaica meant that he knew of, and had great interest in, work by David Picou on urea recycling (Picou \& Phillips, 1972). The idea that urea hydrolysis in the lower gut, liberating $\mathrm{NH}_{3}$ to be utilised for bacterial amino acid synthesis, could also be of importance as a source of amino acids for the host organism had been suggested by evidence from several studies (Giordano et al. 1968; Furst, 1972; Sheng et al. 1977). However, the suggestion that the utilisation of urea- $\mathrm{N}$ in this way in Papua New Guinea highlanders could improve their $\mathrm{N}$ balance on low- and poor-quality-protein diets (Rikimaru et al. 1984) was something Young was very sceptical of. He was also sceptical of Jackson's idea that urea salvage was an important control point in the regulation of $\mathrm{N}$ balance (see Jackson 1998, 1999) since this was contrary to his own work on urea kinetics (El-Khoury et al. 1996). Nevertheless as further evidence emerged from Malcolm Fuller's work with pigs in Aberdeen (for example, Torrallardona et al. 2003) and our own work (Millward et al. 2000), Young set up the appropriate experiments with Fuller and went on to show with $\left[{ }^{15} \mathrm{~N}\right]$ urea and $\left[{ }^{15} \mathrm{~N}^{15} \mathrm{NH}_{3}\right.$ that lysine deriving from intestinal microbial de novo synthesis did indeed appear in the circulating pool (Metges et al. $1999 a, b)$.

The intriguing issue which remains is whether the de novo synthesis of lysine and other indispensable amino acids in the lower gut and absorption into the systemic pool is of any nutritional significance. Young believed that it wasn't. The tragedy of his death deprives us of the person who undoubtedly could have resolved the issue one way or another. 
D. Joe Millward

Centre for Nutrition and Food Safety School of Biomedical and Molecular Sciences University of Surrey Guildford Surrey GU2 7XH $U K$

D.Millward@Surrey.ac.uk

\section{References}

Alexis SD, Young VR \& Gill DM (1974) Concentration of elongation factor 2 in rat skeletal muscle during protein depletion and re-feeding. Biochem J 142, 185-188.

Bolourchi S, Friedmann CM \& Mickelsen O (1968) Wheat flour as a source of protein for human subjects. Am J Clin Nutr 21, $827-835$.

Calloway DH \& Margen S (1971) Variation in endogenous nitrogen excretion and dietary nitrogen utilization as determinants of human protein requirements. J Nutr 101, 205-216.

Carpenter KJ (2003a) A short history of nutritional science: part 1 (1785-1885). J Nutr 133, 638-645.

Carpenter KJ (2003b) A short history of nutritional science: part 2 (1885-1912). J Nutr 133, 975-984.

Carpenter KJ (2003c) A short history of nutritional science: part 3 (1912-1944). J Nutr 133, 3023-3032.

Carpenter KJ (2003d) A short history of nutritional science: part 4 (1945-1985). J Nutr 133, 3331-3342.

Chen SC \& Young VR (1968) Preparation and some properties of rat skeletal muscle polyribosomes. Biochem $J$ 106, 61-67.

El-Khoury AE, Ajami AM, Fukagawa NK, Chapman TE \& Young VR (1996) Diurnal pattern of the interrelationships between leucine oxidation, urea production and hydrolysis in humans. Am J Physiol 271, E563-E573.

El-Khoury AE, Fukagawa NK, Sánchez M, Tsay RH, Gleason RE, Chapman TE \& Young VR (1994) The 24 hour pattern and rate of leucine oxidation, with particular reference to tracer estimates of leucine requirements in healthy adults. Am J Clin Nutr 59, $1012-1020$.

Food and Agriculture Organization (1957) Protein Requirements: Report of the FAO Committee. FAO Nutritional Studies no. 16. Rome: FAO.

Food and Agriculture Organization/World Health Organization (1965) Protein Requirements: Report of a Joint FAO/WHO Expert Group. WHO Technical Report Series no. 301. Geneva: WHO.

Food and Agriculture Organization/World Health Organization (1973) Energy and Protein Requirements. Report of a Joint FAO/WHO Ad Hoc Expert Committee. Technical Report Series no. 522. Geneva: WHO.

Food and Agriculture Organization/World Health Organization/ United Nations University (1985) Energy and Protein Requirements. Report of a Joint FAO/WHO/UNU Expert Consultation. Technical Report Series no. 724. Geneva: WHO.

Furst P (1972) $15 \mathrm{~N}$-studies in severe renal failure. II. Evidence for the essentiality of histidine. Scand J Clin Lab Invest 30, $307-312$.

Garza C, Scrimshaw NS \& Young VR (1977a) Human protein requirements: a long-term metabolic nitrogen balance study in young men to evaluate the $1973 \mathrm{FAO} / \mathrm{WHO}$ safe level of egg protein intake. $J$ Nutr 107, 335-352.

Garza C, Scrimshaw NS \& Young VR (1977b) Human protein requirements: evaluation of the $1973 \mathrm{FAO} / \mathrm{WHO}$ safe level of protein intake for young men at high energy intakes. $\mathrm{Br} J$ Nutr 37, 403-420.
Garza C, Scrimshaw NS \& Young VR (1978) Human protein requirements: interrelationships between energy intake and nitrogen balance in young men consuming the 1973 FAO/ WHO safe level of egg protein, with added nonessential amino acids. $J$ Nutr 108, 90-96.

Gersovitz M, Motil KJ, Munro HN, Scrimshaw NS \& Young VR (1982) Human protein requirements: assessment of the adequacy of the current recommended dietary allowance for dietary protein in elderly men and women. Am J Clin Nutr 35, $6-14$.

Giordano C, de Pascale C, Baliestrieri C, Cittadini D \& Crescenzi A (1968) Incorporation of urea ${ }^{15} \mathrm{~N}$ in amino acids of patients with chronic renal failure on low nitrogen diet. Am J Clin Nutr 21, 394-404.

Hegsted DM (1963) Variation in requirements of nutrients amino acids. Fed Proc 22, 1424-1430.

Hegsted DM (2000) From chick nutrition to nutrition policy. Аnnu Rev Nutr 20, 1-19.

Institute of Medicine (2002) Dietary Reference Intakes for Energy, Carbohydrate, Fiber, Fat, Fatty Acids, Cholesterol, Protein, and Amino Acids (Macronutrients). Washington, DC: National Academy Press.

Irwin MI \& Hegsted DM (1971) A conspectus of research on amino acid requirements of man. J Nutr 101, 539-566.

Istfan N, Murray E, Janghorbani M, Evans WJ \& Young VY (1983a) Nutritional value of a soy protein concentrate (STAPRO-3200) for long-term protein nutritional maintenance in young men. J Nutr 113, 2524-2534.

Istfan N, Murray E, Janghorbani M \& Young VR (1983b) An evaluation of a soy protein concentrate in young men using the short-term $\mathrm{N}$ balance method. $J$ Nutr 113, $2516-2523$.

Jackson AA (1998) Salvage of urea-nitrogen in the large bowel: functional significance in metabolic control and adaptation. Biochem Soc Trans 26, 231-236.

Jackson AA (1999) Limits of adaptation to high dietary protein intakes. Eur J Clin Nutr 53, Suppl. 1, S44-S52.

Jackson AA (2000) Mechanisms of adaptation: the constancy of urea production. In Nutritional Metabolism and Malnutrition: A Festschrift for John Conrad Waterlow, pp. 71-79 [P Shetty, editor]. London: Smith-Gordon.

James WPT \& Hay AM (1968) Albumin metabolism: effect of the nutritional state and the dietary protein intake. J Clin Invest $\mathbf{4 7}$, $1958-1972$.

Kien CL, Rohrbaugh DK, Burke JF \& Young VR (1978a) Whole body protein synthesis in relation to basal energy expenditure in healthy children and in children recovering from burn injury. Pediatr Res 12, 211-216.

Kien CL, Young VR, Rohrbaugh DK \& Burke JF (1978b) Whole body protein synthesis and breakdown rates in children before and after reconstructive surgery of the skin. Metabolism 27, $27-34$.

Kien CL, Young VR, Rohrbaugh DK \& Burke JF (1978c) Increased rates of whole body protein synthesis and breakdown in children recovering from burns. Ann Surg 187, 383-391.

Kurpad AV, Raj T, El-Khoury A, Beaumier L, Kuriyan R, Srivatsa A, Borgonha S, Selvaraj A, Regan MM \& Young VR (2001a) Lysine requirement of healthy adult Indian subjects, measured by an indicator amino acid balance technique. Am J Clin Nutr 73, 900-907.

Kurpad AV, Raj T, El-Khoury A, Kuriyan R, Maruthy K, Borgonha S, Chandukudlu D, Regan MM \& Young VR (2001b) Daily requirement for and splanchnic uptake of leucine in healthy adult Indians. Am J Clin Nutr 74, 747-755.

Kurpad AV, Raj T, Regan MM, Vasudevan J, Caszo B, Nazareth D, Gnanou J \& Young VR (2002a) Threonine requirements of healthy Indian adults, measured by a $24 \mathrm{~h}$ indicator amino 
acid oxidation and balance technique. Am J Clin Nutr 76, 789-797.

Kurpad AV, Regan MM, Nazareth D, Nagaraj S, Gnanou J \& Young VR (2003a) Intestinal parasites increase dietary lysine requirement in chronically undernourished adult Indian men. Am J Clin Nutr 78, 1145-1151.

Kurpad AV, Regan MM, Raj T, El-Khoury A, Kuriyan R, Vaz M, Chandakudlu D, Venkataswamy VG, Borgonha S \& Young VR (2002b) Lysine requirements of healthy adult Indian subjects receiving long-term feeding measured with a $24-\mathrm{h}$ indicator amino acid oxidation and balance technique. Am J Clin Nutr 76, 404-412.

Kurpad AV, Regan MM, Raj T, Varalakshmi S, Gnanou J, Thankachan P \& Young VR (2003b) Leucine requirement and splanchnic uptake of leucine in chronically undernourished adult Indian subjects. Am J Clin Nutr 77, 861-867.

Kurpad AV, Regan MM, Raj T, Vasudevan J, Kuriyan R, Gnanou J \& Young VR (2003c) Lysine requirement of chronically undernourished adult Indian men, measured by the $24 \mathrm{~h}$ indicator amino acid oxidation and balance technique. Am J Clin Nutr 77, 101-108.

Kurpad AV, Regan MM, Varalakshmi S, Gnanou J, Lingappa A \& Young VR (2004) Effect of cystine on the methionine requirement of healthy adult Indian subjects, determined using the $24 \mathrm{~h}$ indicator amino acid balance approach. Am J Clin Nutr, (In the Press).

Kurpad AV, Regan MM, Varalakshmi S, Vasudevan J, Gnanou J, Raj T \& Young VR (2003d) The daily methionine requirements of healthy Indian men, measured by a $24 \mathrm{~h}$ indicator amino acid oxidation and balance technique. Am J Clin Nutr 77, $1198-1205$.

McLaren DS (1974) The great protein fiasco. Lancet ii, 93-96.

Marchini JS, Cortiella J, Hiramatsu T, Chapman TE \& Young VR (1993) Requirements for indispensable amino acids in humans: longer-term amino acid study with support for the adequacy of the MIT amino acid requirement pattern. Am J Clin Nutr 58, $670-683$

Matthews DE, Bier DM, Rennie MJ, Edwards RHT, Halliday D, Millward DJ \& Clugston G (1981) Regulation of leucine metabolism in man: a stable isotope study. Science 214, $1129-1131$

Meguid MM, Matthews DE, Bier DM, Meredith CN, Soeldner JS \& Young VR (1986a) Leucine kinetics at graded leucine intakes in young men. Am J Clin Nutr 43, 770-780.

Meguid MM, Matthews DE, Bier DM, Meredith CN \& Young VR (1986b) Valine kinetics at graded valine intakes in young men. Am J Clin Nutr 43, 781-786.

Meredith C, Bier DM, Meguid MM, Matthews DE, Wen Z \& Young VR (1982) Whole body amino acid turnover with ${ }^{13} \mathrm{C}$ tracers: a new approach for estimation of human amino acid requirements. In Clinical Nutrition '81, pp. 42-59 [RIC Wesdorp and PB Soeters, editors]. London and New York: Churchill Livingstone.

Meredith CN, Wen Z-M, Bier DM, Mathews DE \& Young VR (1986) Lysine kinetics at graded lysine intakes in young men. Am J Clin Nutr 43, 787-794.

Metges CC, El-Khoury AE, Henneman L, Petzke KJ, Grant I, Bedri S, Pereira PP, Ajami AM, Fuller MF \& Young VR (1999a) Availability of intestinal microbial lysine for whole body lysine homeostasis in human subjects. Am J Physiol 277, E597-E607.

Metges CC, Petzke KJ, El-Khoury AE, Henneman L, Grant I, Bedri S, Fuller MF \& Young VR (1999b) Incorporation of urea and ammonia nitrogen into ileal and fecal microbial proteins and plasma free amino acids in normal men and ileostomates. Am J Clin Nutr 70, 1046-1058.
Millward DJ (1990) Amino acid requirements in adult man. Am J Clin Nutr 51, 492-493.

Millward DJ (1994) Can we define indispensable amino acid requirements and assess protein quality in adults? J Nutr 124, 1509 S-1516S.

Millward DJ (2003) An adaptive metabolic demand model for protein and amino acid requirements. Br J Nutr 90, 249-260.

Millward DJ \& Bates PC (1983) 3-Methylhistidine turnover in the whole body: the contribution of skeletal muscle and intestine to urinary 3-methylhistidine excretion in the adult rat. Biochem $J$ 214, 603-615.

Millward DJ, Bates PC, Grimble GK, Brown JC, Natham M \& Rennie MJ (1980) The contribution of non-skeletal muscle tissues to urinary 3-methylhistidine excretion in the rat. Biochem J 190, 225-228.

Millward DJ, Forrester T, Ah-Sing E, Yeboah N, Gibson N, Badaloo A, Boyne M, Reade M, Persaud C \& Jackson A (2000) The transfer of ${ }^{15} \mathrm{~N}$ from urea to lysine in the human infant. Br J Nutr $\mathbf{8 3}$, 505-512.

Millward DJ \& Jackson A (2004) Protein:energy ratios of current diets in developed and developing countries compared with a safe protein:energy ratio: implications for recommended protein and amino acid intakes. Public Health Nutr 7, 387-405.

Osborne T \& Mendel LB (1916) The amino-acid minimum for maintenance and growth as exemplified by further experiments with lysine and tryptophane. J Biol Chem 25, 1-12.

Pencharz PB, Steffee WP, Cochran W, Scrimshaw NS, Rand WM \& Young VR (1977) Protein metabolism in human neonates: nitrogen-balance studies, estimated obligatory losses of nitrogen and whole-body turnover of nitrogen. Clin Sci Molec Med 52, 485-498.

Picou D \& Phillips M (1972) Urea metabolism in malnourished and recovered children receiving a high or low protein diet. Am J Clin Nutr 25, 1261-1266.

Raguso C, Pereira P \& Young VRA (1999) tracer investigation of the obligatory oxidative amino acid losses in healthy, young adults. Am J Clin Nutr 70, 474-483.

Rand WM, Pellett PL \& Young VR (2003) Meta-analysis of nitrogen balance studies for estimating protein requirements in healthy adults. Am J Clin Nutr 77, 109-127.

Rand WM, Scrimshaw NS \& Young VR (1979) An analysis of temporal patterns in urinary nitrogen excretion of young adults receiving constant diets at two nitrogen intakes for 8 to 11 weeks. Am J Clin Nutr 32, 1408-1414.

Rand WM \& Young VR (1999) Statistical analysis of N balance data with reference to the lysine requirement in adults. $J$ Nutr 129, 1920-1926.

Rikimaru T, Fujita Y, Okuda T, Kajiwara N, Date C, Heywood PF, Alpers MP \& Koishi H (1984) Utilization of urea nitrogen in Papua New Guinea highlanders. J Nutr Sci Vitaminol (Tokyo) 31, 393-402.

Rose WC (1957) The amino acid requirements of adult man. Nutr Abstr Rev 27, 631-647.

Scrimshaw NS (1977) W.O. Atwater Memorial Lecture. Through a glass darkly: discerning the practical implications of human dietary protein-energy interrelationships. Nutr Rev 35, 321-336.

Scrimshaw NS (1996) Human protein requirements: a brief update. Food Nutr Bull 17, 185-190.

Scrimshaw NS, Hussein MA, Murray E, Rand WM \& Young VR (1972) Protein requirements of man: variations in obligatory urinary and fecal nitrogen losses in young men. J Nutr 102, 1595-1604.

Scrimshaw NS, Wayler AH, Murray E, Steinke FH, Rand WM \& Young VR (1983) Nitrogen balance response in young men given one of two isolated soy proteins or milk proteins. $J$ Nutr 113, 2492-2497. 
Sheng YB, Badger TM, Asplund JM \& Wixom RL (1977) Incorporation of ${ }^{15} \mathrm{NH}_{4} \mathrm{Cl}$ into histidine in adult man. $J$ Nutr 107, 621-630.

Steffee WP, Goldsmith RS, Pencharz PB, Scrimshaw NS \& Young VR (1976) Dietary protein intake and dynamic aspects of whole body nitrogen metabolism in adult humans. Metabolism 25, 281-297.

Sukhatme PV \& Margen S (1978) Models for protein deficiency. Am J Clin Nutr 31, 1237-1256.

Torrallardona D, Harris CI \& Fuller MF (2003) Lysine synthesized by the gastrointestinal microflora of pigs is absorbed, mostly in the small intestine. Am $J$ Physiol 284, E1177-E1180.

Torun B, Young VR \& Rand WM (editors) (1981) Protein energy requirement studies in developing countries: evaluation of new data. Food Nutr Bull Suppl. 5.

Uauy R, Scrimshaw NS \& Young VR (1978a) Human protein requirements: nitrogen balance response to graded levels of egg protein in elderly men and women. Am J Clin Nutr 31, 779-785.

Uauy R, Winterer JC, Bilmazes C, Haverberg LN, Scrimshaw NS, Munro HN \& Young VR (1978b) The changing patterns of whole body protein metabolism in aging humans. J Gerontol 33, 663-671.

United Nations (1968) International Action to Avert the Impending Protein Crisis. Report to the Economic and Social Council of the Advisory Committee on the Application of Science and Technology to Development. New York: United Nations.

Waterlow JC (1999) The nature and significance of nutritional adaptation. Eur J Clin Nutr 53, Suppl 1, S2-S5.

Waterlow JC, Garlick PJ \& Millward DJ (1978) Protein Turnover in Mammalian Tissues and the Whole Body. Amsterdam: Elsevier/North-Holland Biomedical Press.

Waterlow JC \& Payne PR (1975) The protein gap. Nature 258, $113-117$.

Wayler A, Quieroz E, Scrimshaw NS, Steinke FH, Rand WM \& Young VR (1983) Nitrogen balance studies in young men to assess the protein quality of an isolated soy protein in relation to meat proteins. J Nutr 113, 2485-2491.

Williams CD (1935) A nutritional disease of children associated with a maize diet. Lancet ii, 1151-1152.

Winterer JC, Steffee WP, Davy W, Perera A, Uauy R, Scrimshaw NS \& Young VR (1976) Whole body protein turnover in aging man. Exp Gerontol 11, 79-87.

Young VR (1970) Role of skeletal and cardiac muscle in the regulation of body protein metabolism. In Mammalian Protein Metabolism, Vol. 4, Chapter 40, [HN Munro, editor]. New York: Academic Press, Inc.

Young VR (1992) Protein and amino acid requirements in humans: metabolic basis and current recommendations. Scand $J$ Nutr: Naringsforkning 36, 47-56.

Young VR (1994) Adult amino acid requirements: the case for a major revision in current recommendations. $J$ Nutr 124, $1517 \mathrm{~S}-1523 \mathrm{~S}$.
Young VR, Bier DM \& Pellett PL (1989) A theoretical basis for increasing current estimations of the amino acid requirements in adult man, with experimental support. Am J Clin Nutr $\mathbf{5 0}$, $80-92$.

Young VR \& Borgonha S (1998) Nutritional adaptation (genetic, physiological and behavioral): implications for requirements. In From Nutritional Science to Nutrition Process for Better Global Health, pp. 57-160 [DW Fitzpatrick, JE Anderson and ML L'Abbé, editors]. Ottawa: Canadian Federation of Biological Societies.

Young VR \& Borgonha S (2000) Nitrogen and amino acid requirements: the Massachusetts Institute of Technology amino acid requirement pattern. J Nutr 130, 1841S-1849S.

Young VR, Chen SC \& Macdonald J (1968a) The sedimentation of rat skeletal-muscle ribosomes: effect of hydrocortisone, insulin and diet. Biochem J 106, 913-919.

Young VR \& El-Khoury AE (1995) Can amino acid requirements for nutritional maintenance in adult humans be approximated from the amino acid composition of body mixed proteins? Proc Natl Acad Sci USA 92, 300-304.

Young VR, Fajardo L, Murray E, Rand WM \& Scrimshaw NS (1975a) Protein requirements of man: comparative nitrogen balance response within the submaintenance to maintenance range of intakes of wheat and beef proteins. J Nutr $\mathbf{1 0 5}$, 534-542.

Young VR, Gucalp C, Rand WM, Matthews DE \& Bier DM (1987) Leucine kinetics during three weeks at submaintenance-to-maintenance intakes of leucine in men: adaptation and accommodation. Hum Nutr Clin Nutr 41C, 1-18.

Young VR, Hussein MA \& Scrimshaw NS (1968b) Estimate of loss of labile body nitrogen during acute protein deprivation in young adults. Nature 218, 568-569.

Young VR \& Munro HN (1978) N $\tau$-methylhistidine (3-methylhistidine) and muscle protein turnover. An overview. Fed Proc 37, $2291-2300$.

Young VR \& Scrimshaw NS (1968) Endogenous nitrogen metabolism and plasma amino acids in young adults given a 'proteinfree' diet. Br J Nutr 22, 9-20.

Young VR, Steffee WP, Pencharz PB, Winterer JC \& Scrimshaw NS (1975b) Total human body protein synthesis in relation to protein requirements at various ages. Nature 253, 192-194.

Young VR, Taylor YSM, Rand WM \& Scrimshaw NS (1973) Protein requirements of man: efficiency of egg protein utilization at maintenance and submaintenance levels in young men. J Nutr 103, 1164-1174.

Young VR, Wayler A, Garza C, Steinke FH, Murray E, Rand WM \& Scrimshaw NS (1984) A long-term metabolic balance study in young men to assess the nutritional quality of an isolated soy protein and beef proteins. Am J Clin Nutr 39, 8-15.

Zhao X-H, Wen ZM, Meredith CN, Matthews DE, Bier DM \& Young VR (1986) Threonine kinetics at graded threonine intakes in young men. Am J Clin Nutr 43, 795-802. 